\title{
Alterations in airway mechanics, inflammatory biomarkers and lung histopathology in a rat model of allergen-induced airway inflammation
}

\author{
Stephen M Jordan ${ }^{1 *}$, Rachel A Armstrong ${ }^{1}$, Jennifer Hincks² ${ }^{2}$ David Bell ${ }^{3}$, Kenneth G Meecham \\ From 2nd Cross Company Respiratory Symposium \\ Horsham, UK. 6-7 September 2012
}

The most objective indicator of asthma severity in the clinic is the measurement of reversible airway obstruction by spirometry. We evaluated the effect of antigen challenge on $\mathrm{FEV}_{100}$, FVC and PEF and airway cell infiltrate, cytokine levels and lung histopathology in the Brown Norway rat allergic model. Rats were sensitised to the antigen ovalbumin and challenged by aerosolised ovalbumin fourteen days later. Twenty four hours after challenge the rats were terminally anaesthetised and a forced manoeuvres procedure performed. Recruitment of inflammatory cells and biomarker production was assessed in bronchoalveolar lavage fluid (BALF). Antigen challenge caused a significant $(\mathrm{P}<0.001) 30.2 \pm 2.6,20.5$ \pm 1.7 and $43.0 \pm 3.2 \%$ reduction in $\mathrm{FEV}_{100}$, PEF and FVC.

Exposure to antigen also resulted in the significant recruitment of eosinophils $\left(2.13 \pm 0.60 \times 10^{6}\right.$ cells/animal $)$, neutrophils $\left(2.64 \pm 36 \times 10^{6}\right.$ cells/animal $)$ and lymphocytes $\left(0.53 \pm 0.05 \times 10^{6}\right.$ cells/animal $)$ into the airway. The Th2 cytokines; IL-13 and IL- 5 and macrophage derived TNF- $\alpha$ in addition to IL- 6 and MIP- $1 \alpha$ levels were significantly elevated in the BALF. Oral treatment with a glucocorticoid steroid budesonide $(3 \mathrm{mg} / \mathrm{kg}$ ) twice daily completely reversed the decline in $\mathrm{FEV}_{100}$, PEF and FVC and significantly $(\mathrm{P}<0.001)$ reduced the inflammatory cell infiltrate, cytokine secretion and reduced the percentage incidences and severity of granulomatous inflammation. We have demonstrated that allergen challenge results in a reversible decline in measured $\mathrm{FEV}_{100}$, $\mathrm{PEV}$ and $\mathrm{FVC}$ in a rat allergic model. This functional measurement may be a valuable tool for translating the efficacy of novel compounds from rodents to the clinic.

'Department of Pharmacology, Huntingdon Life Sciences, Cambridgeshire, UK

Full list of author information is available at the end of the article

\section{Authors' details}

'Department of Pharmacology, Huntingdon Life Sciences, Cambridgeshire, UK. ${ }^{2}$ Department of Biomarkers, Bioanalysis and Clinical Sciences, Huntingdon Life Sciences, Cambridgeshire, UK. ${ }^{3}$ Department of Pathology, Huntingdon Life Sciences, Cambridgeshire, UK.

Published: 14 August 2013

doi:10.1186/1476-9255-10-S1-P8

Cite this article as: Jordan et al: Alterations in airway mechanics, inflammatory biomarkers and lung histopathology in a rat model of allergen-induced airway inflammation. Journal of Inflammation 201310 (Suppl 1):P8.

Submit your next manuscript to BioMed Central and take full advantage of:

- Convenient online submission

- Thorough peer review

- No space constraints or color figure charges

- Immediate publication on acceptance

- Inclusion in PubMed, CAS, Scopus and Google Scholar

- Research which is freely available for redistribution 